\title{
ANALISIS TERHADAP PREMIUM REMEDIUM TERKAIT SANKSI HUKUM LINGKUNGAN
}

\author{
Rumbadi \\ Dosen Tetap Prodi Ilmu Hukum Universitas Riau Kepulauan Batam
}

\begin{abstract}
ABSTRAK
Pulau Batam sebagai kawasan Perdagangan dan Pelabuhan Bebas sesuai UndangUndang Nomor 27 Tahun 2007, dan Peraturan Pemerintah Nomor 1 Tahun 2007. Batam sebagai kawasan Perdagangan dan Pelabuhan Bebas termasuk Pulau Tonton, Pulau Setokok, Pulau Nipah, Pulau Rempang, Pulau Galang, Pulau Galang Baru, Manfaat diterapkannya kawasan perdagangan dan pelabuhan bebas 34 negara telah berinvestasi di sini.Konsekuensi status Free Trade Zone adalah banyaknya investor yang berdampak negatif di satu sisi, dan dampak positif di sisi lain.

Dampak negatif adalah kerusakan lingkungan hidup akibat dari kegiatan usaha perusahaan tersebut, perusahaan ada yang memproduksi limbah bahan berbahaya dan beracun (B3), bahkan ada perusahaan pengimpor Limbah B3 masuk ke Indonesia seperti PT. Jace Octavia Mandiri . Stockholm Convention 1972, Basel Convention on the Control of Trans boundary Movement on Hazardous Waste and Their Disposal. Indonesia meratifikasi Konvensi Stockholm itu menerbitkan Undang-Undang Nomor 32 Tahun 2009 Tentang Perlindungan dan Pengelolaan Lingkungan Hidup menggantikan Undang-Undang Nomor 27 Tahun 1997 Tentang Pengelolaan Lingkungan Hidup.

Pemerintah Kota Batam berhadapan dengan pilihan yang sulit dalam penerapan sanksi sesuai Undang-Undang Nomor 32 Tahun 2009 Tentang Perlindungan dan Pengelolaan Lingkungan Hidup, sebab dalam peraturan itu, sanksi administrasi (Ultimum Remedium) lingkungan harus dikedepankan sebelum melangkah sanksi lain yakni sanksi Pidana (Premium Remedium).
\end{abstract}

Kata Kunci: Limbah B3, Free Trade Zone Batam

\section{A. PENDAHULUAN}

Batam sebagai daerah industri memiliki konsekuensi banyaknya perusahaan penghasil limbah bahan berbahaya dan beracun (B3). Penghasil Limbah B3 itu tidak hanya dihasilkan oleh perusahaan-perusahaan besar seperti shipyard, tapi juga limbah rumah tangga, dengan penduduk hingga Juni 2014 sebanyak 1,169,761 jiwa ${ }^{1}$ menghasilkan limbah biotik dan abiotik

\footnotetext{
${ }^{1}$ Majalah Batam Indonesia Free Trade Zone Authority, Development Progress of Batam, Tahun 2014, Edisi 1 Volume XXV, Pusat Pengelolaan Data \& Sistem Informal (PPDSI) Badan Pengusahaan Kawasan Perdagangan Bebas dan Pelabuhan Bebas Batam,
} 
Konsekuensi dari bertambah pekerja dan penduduk di Batam dengan menghasilkan rumah tangga dengan komposisi Sampah di Kota Batam sebagai brikut: Tahun 2008 total tonase 178,045 ton yang terdiri dari sampah organik 106,790 ton dan sampah non organic 71.255 ton, dan tahun 2012 meningkat menjadi total sampah 213,138 ton yang peningkatan seberat 4.140 ton $(1,98 \%)$ yang untuk sampah organic 128,119 ton dan sampah non organic 80,880 ton. Jika dilihat dari komposisi limbah organic dan non organik untuk limbah rumah tangga 70 persen organic dan non organik 30 persen, sedangkan sumber dari industri 70 persen berbanding terbalim dan limbah non organik 70 persen merupakan limbah B3, dan organik 30 persen. $^{2}$

Limbah B3 tidak hanya dari hasil produksi perusahaan-perusahaan di Batam, dan rumah tangga, tapi ada pula perusahaan yang mengimpor limbah B3 yakni PT. Asia Pacifik Eco Lestari selanjutnya disingkat PT.APEL mengimpor limbah B3 dari Singapura seberat 1.700 ton, dan PT. Jace Octavia Mandiri selanjutnya PT.JOM mengimpor limbah B3 dari Korea Selatan seberat 3.800 ton. Kedua perusahaan tersebut melanggar Undang-Undang Nomor 32 Tahun 2009 Tentang Perlindungan dan Pengelolaan Lingkungan Hidup, dan merupakan kejahatan.

Kementerian Lingkungan Hidup telah memastikan bahwa limbah B3 yang dipasok oleh PT. JOM merupakan limbah B3 jenis cooper slag. Cooper Slag ini diimpor dari Korea Selatan pada 4 Februari 2009 sebanyak 3.800 ton. Hasil Uji Laboratorium Kementerian Lingkungan Hidup menyebutkan Limbah B3 memiliki kode Harmoninasi Sistem (HS) 2505.90.000, jadi barang tersebut berasal dari LS-Niko Copper Inc, Korea Selatan, dalam akte notaris PT. JOM enyebut bahwa limbah yang diimpor PT. JOM berasal dari sebuah perusahaan peleburan/produksi tembaga. Maka limbah B3 itu sisa atau residu peleburan tembaga (copper), dan merupakan limbah B3 dengan kode ilmiah D211. ${ }^{3}$

Berdasarkan Undang-Undang Nomor 32 Tahun 2009 Tentang Perlindungan dan Pengelolaan Lingkungan Hidup mengimpor limbah B3 itu dilarang. Pasal 106 dan Pasal 107 menyebutkan dilarang memasukkan limbah B3 ke wilayah Republik Indonesia, sesuai Konvensi Basel. Konvensi ini melarang ekspor limbah B3 ke Negara yang tidak mampu mengelola secara berwawasan lingkungan. Indonesia telah meratifikasi konvensi Basel melalui

\footnotetext{
${ }^{2}$ Rapat Stake Holders Eksekutif Pengelolaan Sampah Kota Batam, 21 Nopember 2012 di Hotel Swiss Inn Batam

${ }^{3}$ Irma Anshari, Pengelolaan Limbah dan Penanganan Limbah B3, Diambil pada 29 Agustus 2014 http://limbahb3-limbahb3.blogspot.com/ di akses Hari: Kamis, 4 Februari 2016 Pukul.21.00 WIB
} 
Keputusan Presiden Nomor 5 Tahun 1993 dan Keputusan Presiden Nomor 61 Tahun 1993 Tentang Pengesahan di Pasal 1, tentang Basel Convention On The Control Of Transboundary Movements Of Hazardous Wastes And Their Disposal. Kemudian Keputusan Presiden Indonesia Nomor 47 Tahun 2005 Tentang Pengesahan Amandement to The Basel Convention on the Control of Transboundary Movement of Hazardous Wastes and Their Disposal.

Indonesia meratifikasi hasil-hasil konvensi dengan menerbitkan 3 (tiga) kali peraturan perundang-undangan berkaitan dengan lingkungan hidup yakni:

1. Undang-Undang Nomor 4 Tahun 1982 tentang Ketentuan Pokok Pengelolaan Lingkungan Hidup (KPPLH);

2. Undang-Undang Nomor 23 Tahun 1997 tentang Pengelolaan Lingkungan Hidup (UUPLH); dan

3. Undang-Undang Nomor 32 Tahun 2009 tentang Perlindungan dan Pengelolaan Lingkungan Hidup (UUPPLH).

Namun dalam Undang-Undang Nomor 32 Tahun 2009 Tentang Perlindungan dan Pengelolaan Lingkungan Hidup, sanksi terhadap pelangaran Lingkungan Hidup tidak serta merta sanksi pidana, tapi melalui tahapan yakni: Sanksi Administrasi (Ultimum Remedium), Sanksi Perdata, dan Sanksi Pidana (Premium Remedium)

\section{B. Metode Penelitian}

Data yang dikumpulkan adalah data kualitatif maka teknik analisa datanya menggunakan model analisas kualitatif interaktif. Dalam teknik analisa data ini setelah data terkumpul selanjutnya bisa dikemukakan dalam sajian data ataupun dengan langkah mengolah data (mereduksi data) yang diperoleh dari sumber kepustakaan (literature-literatur, undangundang, surat khabar maupun sumber kepustakaan lainnya), ataupun dari data-data yang diperoleh di lapangan dari informan yang berkompeten dalam memberikan data mengenai Lingkungan Hidup khususnya limbah B3 berdasarkan Undandang-Undang Nomor 32 Tahun 2009 Tentang Perlindungan dan Pengelolaan Lingkungan Hidup. ${ }^{4}$

Dalam penelitian ini, peneliti menggunakan jenis penelitian hukum empiris, yaitu asumsi dasarnya dari optik sosiologis adanya perbedaan antara hukum tertulis (das sollen)

\footnotetext{
${ }^{4}$ DR.H.Salim HS, S.H.,M.S., dan Elis Septiana Nurbani, S.H., LLM, (Cet.Kedua), Penerapan Teori Hukum Pada
} Penelitian Tesis dan Disertasi, Jakarta: PT.Rajagrafindo Persada, 2013. Hal.25 
dengan hukum yang hidup di tengah masyarakat (das sein) atau yang merupakan fakta. Fakta tersebut kemudian ditelaah berdasarkan kerangka sebab-akibat. ${ }^{5}$

Data yang dikumpulkan adalah data kualitatif maka teknik analisa datanya menggunakan model analisa kualitatif interaktif. Dalam teknik analisa data ini setelah data terkumpul selanjutnya bisa dikemukakan dalam sajian data ataupun dengan langkah mengolah data (mereduksi data) yang diperoleh dari sumber kepustakaan (literature-literatur, undangundang, surat khabar maupun sumber kepustakaan lainnya), ataupun dari data-data yang diperoleh di lapangan dari informan yang berkompeten dalam memberikan data mengenai Lingkungan Hidup khususnya limbah B3 berdasarkan Undandang-Undang Nomor 32 Tahun 2009 Tentang Perlindungan dan Pengelolaan Lingkungan Hidup.

Pendekatan yang digunakan adalah pendekatan yuridis empiris yang dilakukan dengan penelitian lapangan, yaitu melihat fakta-fakta yang ada dalam praktik dan mengenai pelaksanaannya. Dalam penelitian ini, populasi terdiri Badan Pengendalian Dampak Lingkungan Kota Batam, Lembaga Swadaya Masyarakat Gerakan Bersama Rakyat ( LSM GEBRAK) Kota Batam, Pengadilan Kota Batam. Serta masyarakat yang terkena dampak Limbah B3 milik PT.JOM di sekitar Perumahan Putri Hijau, Batu Aji Batam.

Untuk menentukan sampel dari populasi digunakan metode propersional purposive sampling yang berarti bahwa dalam menentukan sampel disesuaikan dengan tujuan yang hendak dicapai dan proporsi masing-masing sampel yang dianggap mewakili populasi terhadap masalah yang hendak diteliti/dibahas. ${ }^{6}$

Untuk menganalisis data yang telah terkumpul penulis menggunakan analisis kualitatif. Analsisis kualitiatif dilakukan untuk melukiskan kenyataan-kenyataan yang ada berdasarkan hasil penelitian yang berbentuk penjelasan-penjelasan, dari analisis tersebut dapat ditarik suatu kesimpulan secara industif, yaitu cara berpikir dalam mengambil suatu kesimpulan terhadap permasalahan yang membahas secara umum yang didasarkan atas fakta-fakta yang bersifat khusus. $^{7}$

\section{Hasil Penelitian dan Pembahasan}

\footnotetext{
5“"Eddy Rifai”, Perspektif Pertanggungjawaban Pidana Korporasi sebagai Tindak Pidana Korupsi, Mimbar Hukum, Volume 1, 26 Februari 2014, hlm.87-88

${ }^{6}$ ibid

7 ibid
} 
Undang-Undang Nomor 32 Tahun 2009 Tentang Perlindungan dan Pengelolaan Lingkungan Hidup Pasal 1 ayat (2) menyebutkan: Perlindungan dan Pengelolaan Lingkungan Hidup adalah upaya sistematis dan terpadu yang dilakukan untuk melestarikan fungsi lingkungan hidup dan mencegah terjadinya pencemaran dan/atau kerusakan lingkungan hidup yang meliputi perencanaan, pemanfaatan, pengendalian, pemeliharaan, pengawasan, dan penegakan hukum.

Dilihat dari konseptual diatas, maka pengendalian, pengawasan dan penegakkan hukum menyangkut lingkungan hidup mendapat prosi yang baik, apalagi dikaitkan dengan peraturan perundang-undangan yang berlaku. Turunan Undang-Undang Nomor 32 Tahun 2009 Tentang Perlindungan dan Pengelolaan Lingkungan Hidup yakni:

1. Peraturan Pemerintah Nomor 101 Tahun 204 Tentang Pengelolaan Libah Bahan Berbahaya dan Beracun Peraturan Pemerintah Nomor 27 Tahun 2012 Tentang Ijin Lingkungan Hidup

2. Peraturan Pemerintah Nomor 27 Tahun 2012 Tentang Ijin Lingkungan Hidup

3. Peraturan Menteri Negara Lingkungan Hidup Nomor 01 Tahun 2012 Tentang Program Menuju Indonesia Hijau

4. Peraturan Menteri Negara Lingkungan Hidup Nomor 05 Tahun 2012 Tentang Jenis Rencana Usaha dan/atau Kegiatan yang wajib Memiliki Analisis dampak lingkungan yang selanjutanya disingkat AMDAL

5. Peraturan Menteri Negara Lingkungan Hidup Nomor 17 Tahin 2012 Tentang Pedoman Keterlibatan masyarakat Dalam Proses AMDAL

Mengimpor limbah B3 seperti dilakukan oleh PT.APEL dan PT.JOM merupakan perbuatan melawan hukum karena sesuai dengan bunyi Pasal 21 Undang-Undang Nomor 23 Tahun 1997 Tentang Pengelolaan Lingkungan Hidup yang menyebutkan:" Setiap orang dilarang melakukan impor limbah berbahaya dan beracun.

Undang-Undang Nomor 32 Tahun 2009 Tentang Perlindungan dan Pengelolaan Lingkungkan Hidup di Pasal 97 disebutkan Tindak Pidana dalam Undang-Undang ini merupakan kejahatan. Oleh sebab itu, mengimpor limbah B3 selain merupakan tindak kejahatan, juga melawan hukum. Tindakan melawan hukum bermakna mengingkari apa yang telah ditentukan pemerintah.

Selain itu dalam Konvensi Basel Convention on the Control of Transboundary Movement on Hazardouz Waste and their Disposal. Konvensi ini mengatur tentang pengawasan perpindahan lalu lintas batas limbah B3 dan pembuangannya/penyimpanannya. 
Konvensi ini melarang ekspor limbah B3 ke Negara yang tidak mampu mengelola secara berwawasan lingkungan.

Indonesia telah meratifikasi konvensi Basel melalui Keputusan Presiden Nomor 5 Tahun 1993 dan Keputusan Presiden Nomor 61 Tahun 1993 Tentang Pengesahan Basel Convention On The Control Of Transboundary Movements Of Hazardous Wastes And Their Disposal. Pasal 1 disebutkan: Mengesahkan Basel Convention on the Control of Transboundary Movements of the Hazardous Wastes and Their Disposal yang telah diterima di Basel, Swiss, pada tanggal 22 Maret 1989 sebagai hasil the Conference of Plenipotentiaries on the Global Convention on the Control of Transboundary Movements of Hazardous Wastes yang diselenggarakan oleh United Nations Environment Programme (UNEP), dengan suatu Pernyataan (Declaration) yang salinan naskah aslinya dalam bahasa Inggris sebagaimana terlampir pada Keputusan Presiden Indonesia Nomor 47 Tahun 2005 Tentang Pengesahan Amandement to The Basel Convention on the Control of Transboundary Movement of Hazardous Wastes and Their Disposal.

Sejak Konvensi Stockhlom, Indonesia meratifikasi hasil-hasil konvensi dengan menerbitkan tiga kali peraturan perundang-undangan berkaitan dengan lingkungan hidup yakni:

1. Undang-Undang Nomor 4 Tahun 1982 tentang Ketentuan Pokok Pengelolaan Lingkungan Hidup;

2. Undang-Undang Nomor 23 Tahun 1997 tentang Pengelolaan Lingkungan Hidup (UUPLH); dan

3. Undang-Undang Nomor 32 Tahun 2009 tentang Perlindungan dan Pengelolaan Lingkungan Hidup (UUPPLH).

Namun dalam kasus pelanggaran di bidang lingkungan hidup tidak serta merta sanksi pidana diterapkan, tapi melalui proses lain seperti: Hukum Lingkungan Administrasi, Hukum Lingkungan Perdata, dan ada pula Alternatif Penyelesaian Sengketa.

Sanksi terhadap individu dan/atau badan hukum yang melanggar peraturan perundangundangan bidang lingkungan hidup tidak serta merta sanksi hukum pidana yang diterapkan. Karena dalam hukum lingkungan hidup terdapat tahapan yang harus dilaksanakan terlebih dahulu dengan berpegang pada asas Ultimum Remedium dan Primum Remedium. UndangUndang Nomor 23 Tahun 1997 Tentang Pengelolaan Lingkungan Hidup, ada yang disebut asas 
Subsidiaritas, kemudian asas ini dihilangkan dalam Undang-Undang Nomor 32 Tahun 2009 Tentang Perlindungan dan Pengelolaan Lingkungan Hidup diganti dengan asas Ultimum Remedium. Asas-asas tersebut terkait dengan sanksi-sanksi hukum lingkungan hidup sebelum sanksi Pidana. Sarana Penegakan Hukum Lingkungan Hidup adalah sebagai berkut :

\section{D.1.Sanksi Hukum Administratif Lingkungan Hidup}

Sanksi Hukum Administratif Lingkungan Hidup merupakan langkah preventif, dan menerapkan asas Ultimum Remedium. Sanksi ini bertitik tolak dari syarat-syarat pendirian perusahaan yang terlebih dahulu memperoleh ijin terutama ijin lingkungan hidup, dan dokumen perijinan ini diterbitkan oleh pemerintah dan pemerintah daerah Kabupaten/Kota.

Sifat dari sanksi Administrasi adalah reparatoir, memulihkan pada keadaan semula. Oleh karena itu tanpa mengecilkan makna dari sanksi hukum yang lainnya, penerapan sanksi administrasi dalam kasus lingkungan mempunyai peranan yang sangat penting dalam upaya mencegah dan menanggulangi terjadinya pencemaran lingkungan. Pemberian wewenang kepada Pemerintah untuk menerapkan sanksi administrasi dalam kasus lingkungan hidup seharusnya menjadi konsekuensi logis dari kewenangan Pemerintah dalam perlindungan dan pengelolaann lingkungan hidup.

Penegakan Hukum Lingkungan Administratif yang berupa pengawasan dan penerapan sanksi administrasi dalam Undang-Undang Nomor 32 Tahun 2009 Tentang Perlindungan dan Pengelolaan Lingkungan Hidup telah diatur dalam Pasal 76 sampai dengan Pasal 83, Pasal 76.

Dalam ketentuan Undang-Undang Nomor 32 Tahun 2009 Tentang Perlindungan dan Pengelolaan Lingkungan Hidup, Paksaan Pemerintah sebagaimana dimaksud dalam Pasal 76 ayat (2) menyebutkan:” Sanksi Adinistratrif terdiri atas:

a. Teguran Tertulis;

b. Paksaan Pemerintah;

c Pembekuan Ijin Lingkungan; dan

d. Pencabutan ijin lingkungan

Tindakan lain yang bertujuan untuk menghentikan pelanggaran dan tindakan memulihkan fungsi-fungsi lingkungan hidup. Selain itu, pengenaan paksaan pemerintah dapat dijatuhkan tanpa didahului teguran apabila pelanggaran yang dilakukan menimbulkan : 
1. Ancaman yang sangat serius bagi manusia dan lingkungan hidup;

2. Dampak yang lebih besar dan lebih luas jika tidak segera dihentikan pencemaran dan/atau perusakannya; dan/atau

3. Kerugian yang lebih besar bagi lingkungan hidup jika tidak segera dihentikan pencemaran dan/atau perusakan.

Penerapan sanksi administrasi dalam kasus pencemaran lingkungan merupakan salah satu bentuk dari tindak pemerintahan (bestuurshandelingan) semua yang dilakukan dalam rangka penegakan hukum lingkungan. Oleh karena itu, kajian teoritis tentang penerapan sanksi administrasi tidak terlepas dari pembahasan tentang profesionalisme pemerintahan. Tindak pemerintahan meliputi semua perbuatan yang dilakukan oleh organ administrasi dalam rangka menyelenggarakan tugas pemerintahan, dan seluruh kegiatan negara di luar kegiatan pembentukan undang-undang dan peradilan. Hal ini sejajar dengan pengertian "besturen" atau pemerintahan dalam arti sempit. Pemerintahan dalam arti luas (regering) meliputi membuat peraturan (regel geven) pemerintahan dalam arti sempit (besturen), dan mengadili (geschil neslechting). Prajudi Atmosudirjo menggunakan istilah kegiatan administrasi Negara dalam hal tugas pemerintahan tersebut.

Hukum Lingkungan Administrasi yang dikedepankan bagi pelanggar undang-undang lingkungan, maka ini berdampak pada kurang efektifnya UUPPLH, sebab hukum administrasi hanya pada tataran pemeriksaan dokumen-dokumen perijinan, sementara kerusakan telah terjadi, bahkan perusahaan yang telah mencemari tanah, air, dan udara, dan perusahaan tersebut telah menutup sendiri perusahaannya.

Pendapat lain dikemukakan oleh para ahli lingkungan hidup yakni. Sanksi Hukum Administrasi Negara yaitu alat kekuasaan yang bersifat hukum publik yang dapat digunakan oleh Pemerintah norma Hukum Adminstrasi Negara yang selanjutnya disingkat HAN. Berdasarkan definisi ada empat unsur sanksi dalam HAN, yaitu: ${ }^{8}$

1. Alat kekuasaan (machtmiddelen);

2. Bersifat Hukum Publik (publiekrechtelijke);

3. Digunakan oleh Pemerintah (overhead);

4. Sebagai reaksi atas ketidakpatuhan (reactive op niet-naleving).

Apabila proses hukum bergulir ke Pengadilan karena disangkakan bersalah telah melanggar peraturan perundang-undangan lingkungan hidup yang berlaku, maka para yuris

\footnotetext{
${ }^{8}$ Ridwan HR (Ed.Rev.7), Hukum Administrasi Negara, Jakarta: PT. Grafindo Persada, 2011. hlm.297
} 
pun harus lebih merinci apa delik formil dan delik materiilnya. Ini penting karena berpaut pada asas legalitas.

Akibat penegakan hukum yang ambigu membuat hukum itu sendiri tidak ditaati. Hukum yang tidak ditaati oleh masyarakat merupakan peraturan perundang-undangan tersebut tidak efisien, yang akibat dalam membuat undang-undang tidak berasaskan pada filisofis, historis dan sosiologis, sehingga kurangnya kesadaran hukum lingkungan hidup bagi masyarakat.

Untuk memelihara dan/atau menjaga kelestarian lingkungan hidup harus ada kesadaran hukum dari setiap orang/individu dan/atau badan hukum. Pejabat Kehakiman R.I membedakan kesadaran hukum itu. Menteri Kehakiman Republik Indonesia, Oetojo Oesman membedakan kesadaran hukum sebagai berikut: ${ }^{9}$

1. Kesadaran Hukum yang baik,

2. Kesadaran Hukum yang buruk

Ketaatan Hukum sendiri masih dapat dibedakan kualitasnya dalam tiga jenis yakni:

1. Ketaatan hukum yang bersifat compliance, yaitu jika seseorang taat terhadap suatu aturan hanya karena ia takut terkena sanksi;

2. Ketaatan yang bersifat identification, yaitu jika seseorang taat terhadap suatu aturan hanya karena takut hubungan baiknya dengan seseorang menjadi rusak;

3. Ketaatan yang bersifat internalization, yaitu jika seseorang taat terhadap suatu aturan benar-benar karena ia merasa aturan itu sesuai dengan nilai-nilai intrinsik yang dianutnya.

Oleh sebab itu, seharusnya bagi pembuat peraturan perundang-undangan (pemerintah dan social live) seyogyanya melihat gejala sosial, sehingga hukum itu bisa diterima dan sesuai dengan keinginan masyarakat yakni tercapai rasa keadilan oleh hukum itu sendiri. Law in book hal yang mengikat, dan bagi warga masyarakat yang tidak mentaatinya, maka akan terkena sanksi (hukuman).

Kelompok-kelompok sosial, politik dan ekonomi tertentu ini karena dalam proses pembuatan peraturan perundang-undangan melibatkan orang-orang politik yang tak tertutup kemungkinan masuknya kepentingan-kepentingan kelompok dalam pengesahan peraturan perundang-undangan dan/atau hukum.

\section{D.2. Sanksi Hukum Perdata Lingkungan Hidup}

${ }^{9}$ ibid 
Sanksi hukum lingkungan hidup dapat juga diterapkan hukum perdata. Upaya yang dapat dilakukan dengan cara mengajukan gugatan ke Pengadilan Negeri. Berdasarkan Pasal 1365 Kitab Undang-Undang Hukum Acara Perdata (KUHAPer). Logika hukum penggunaan upaya tersebut adalah sebagai berikut:

a).Perbuatan penanggungjawab usaha tidak membayar denda keterlambatan paksaan pemerintah merupakan perbuatan melanggar hukum, karena bertentangan dengan kewajiban yang telah ditetapkan dengan peraturan perundang-undang;

b).Denda keterlambatan paksaan pemerintah dapat digolongkan sebagai kerugian;

c).Tidak membayar denda keterlambatan paksaan pemerintah meskipun telah ada surat perintah sebelum dilakukan tindakan nyata, merupakan indikator adanya kesengajaan untuk tidak memenuhi kewajibannya. Kesengajaan merupakan salah satu bentuk kesalahan.

Mengenai hal ini perlu dibedakan antara penerapan hukum perdata oleh instansi yang berwenang melaksanakan kebijaksanaan lingkungan dan penerapan hukum perdata untuk memaksakan kepatuhan terhadap peraturan perundang-undangan lingkungan. Misalnya, penguasa dapat menetapkan persyaratan persyaratan perlindungan lingkungan terhadap penjualan atau pemberian hak membuka tanah (erfpacht) atas sebidang tanah. Selain itu terdapat kemungkinan "beracara singkat" (kortgeding) bagi pihak ketiga yang berkepentingan untuk menggugat kepatuhan terhadap undang-undang dan permohonan agar terhadap larangan atau keharusan dikaitkan uang paksa (injuction).

\section{D.3.Alternatif Penyelesaian Sengketa/Alternatif Dispute Resolution}

Penyelesaian sengketa Lingkungan Hidup di Luar Pengadilan dapat dilakukan. Ini termaktub di Pasal 85 ayat (1) ayat (2), dan ayat (3), Undang-Undang Nomor 32 Tahun 2009 Tentang Perlindungan dan Pengelolaan Lingkungan Hidup. Pasal 1 menyebutkan, penyelesaian sengketa lingkungan hidup di luar pengadilan dilakukan untuk mencapai kesepakatan mengenai Bentuk dan besarnya ganti rugi; ${ }^{10}$

a. Tindakan pemulihan akibat pencemaran dan/atau perusakan;

\footnotetext{
${ }^{10}$ D.Y. Witanto, Hukum Acara Mediasi Dalam Perkara Perdata di Lingkungan Peradilan Umum dan Peradilan Agama Menurut PERMA No.1 Tahun 2008 Tentang Prosedur Mediasi di Pengadilan, Bandung: Alfabeta, 2011, hlm.11-13
} 
b.Tindakan tertentu untuk menjamin tidak akan terulangnya pencemaran dan/atau perusakan; dan/atau

c.Tindakan untuk mencegah timbulnya dampak negatif terhadap lingkungan hidup

Dalam hal Penyelesaian sengketa lingkungan hidup di luar pengadilan, maka disebutkan di dalam Pasal 1 angka 1 Undang-Undang Nomor 30 Tahun 1999 Tentang Arbitrase dan Alternatif Penyelesaian Sengketa (Alternatif Dispute Resolution/ADR). "Arbitrase adalah cara penyelesaian suatu sengketa perdata di luar peradilan umum yangdidasarkan pada perjanjian arbitrase yang dibuat secara tertulis oleh para pihak yang bersengketa.

Tindakan PT. JOM dan PT. APEL mengimpor limbah B3 dapat digolongkan perbuatan mala in se. Ini mengacu pada Undang-Undang Nomor 23 Tahun 1997 Tentang Pengelolaan Lingkungan Hidup. Yang didalamnya mengandung ketentuan pidana mulai Pasal 41 sampai Pasal 48. Pasal 43, Pasal 45 Untuk tindak pidana lingkungan hidup dan dikategorikan tindakan kejahatan termaktub dalam Pasal 48

Dalam kontek studi kejahatan, perbuatan pidana disebut sebagai legal definition of crime. Dalam perspektif hukum pidana, legal definition of crime dibedakan menjadi apa yang disebut mala in se dan mala prohibita. Dapat dikatakan mala in se adalah perbuatan-perbuatan yang sejak awal telah dirasakan sebagai suatu ketidakadilan karena bertentangan dengan kaidah-kaidah dalam masyarakat oleh undang-undang sebagai suatu perbuatan pidana. Maka mala in se disebut sebagai kejahatan. Asas Premium Remedium dapat diterapkan, tidak perlu melalui asas Ultimum Remedium atau Hukum Administrasi

Hukum pidana mempunyai keterkaitan dengan ideologi politik suatu bangsa, karena pengaturan materi hukum pidana merupakan pencerminan dari ideologi politik dan seluruh bangunan hukum itu bertumpu pada pandangan ideologi politik yang sehat dan konsisten dari suatu bangsa.

F.A. Allen mengatakan, tujuan hukum pidana adalah untuk melindungi dan memelihara ideologi politik atau the basic political values, karena menurut dia, the central problem of the criminal law is and will remain political in character, yang berarti masalah yang paling mendasar dan sentral dalam hukum pidana adalah pencapaian berbagai tujuan dari tertib 
masyarakat melalui penggunaan kekuasaan yang diatur sedemikian rupa untuk melindungi dan memelihara nilai-nilai dasar yang bersifat politik atau nilai-nilai yang mendasar. ${ }^{11}$

Penerapan sanksi administrasi dengan asas ultimum remedium tidak menjadikan pelanggar peraturan perundang-undangan terkait lingkungan hidup patuh sepenuhnya, bahkan terkesan melawan hukum. Syahrul Mahmud, mengutip Fangman yang mengatakan bahwa, pendapat yang mengatakan penerapan hukum pidana merupakan ultimum remedium telah ditinggalkan di negeri Belanda, karena hal ini menimbulkan pertengkaran disana antara Pejabat Adminsitrasi dan Penuntut Umum tentang kapan tiba saatnya penggunaan obat terakhir itu (hukum pidana).

Undang-Undang Nomor 32 Tahun 2009 Tentang Perlindungan dan Pengelolaan Lingkungan Hidup pun telah menerapkan asas primum remedium untuk penerapan sanksi pidana, namun persoalannya serupa sampai kapan tiba saatnya premum remedium bakal diterapkan apabila hanya mengedepankan sanksi administrasi, padahal sepatutnya sanksi pidana bagi pelanggar peraturan perundang-undangan menyangkut lingkungan hidup, apalagi seperti PT. JOM yang mengimpor limbah B3 dari Negara Korea Selatan, padahal itu dilarang undang-undang. ${ }^{12}$

Muladi mengutip pendapat August Bequai, bahwa perbuatan pidana lingkungan dikelompokkan sebagai salah satu bentuk white collar crime, selain securities related crime, bankruptcy frauds, bribes, kickbacks and political frauds, consumer related frauds in government contracts and programs, insurance frauds, insider related frauds, antitrust and restraint of trade practices, crime by computer dan tax frauds. Dalam environmental crimes justru trend to injure, maim or destroy on a larger scale than the acts of the traditional felon. Oleh sebab itu, menurut Muladi dalam kerangka itu semua, masihkah kita memandang hukum pidana bersifat subsidiaritas kini ultimum remedium.? Tidak perlukah demi kepentingan nasional hukum perdata dan hukum administrasi sebagai obat utama/premium remedium. ${ }^{13}$

\section{D.4. Sanksi Hukum Pidana Lingkungan Hidup}

\footnotetext{
${ }^{11}$ Junivert Girsang, Abuse of Power Penyalahgunaan Kekuasaan Aparat Penegak Hukum Dalam Penanganan Tindak Pidana Korupsi, Jakarta: JG Publishing, 2012, hlm.47 
Sanksi Hukum Pidana Lingkungan Hidup merupakan upaya terakhir setelah upaya lain seperti Sanksi Hukum Administrasi, Sanksi Hukum Perdata, Alternatif Penyelesaian Sengketa mengalami kebuntuan, dan/atau tidak dapat menyelesaikannya.

Undang-Undang Nomor 32 Tahun 2009 Tentang Perlindungan dan Pengelolaan Lingkungan Hidup menyebutkan, upaya represif ini menerapkan azas, Premium Remedium sedangkan upaya terdahulu adalah penerapan asas Ultimum Remedium. Dalam hal untuk mengaplikasikan sanksi hukum pidana terhadap seorang dan/atau badan hukum/ korporasi yang melanggar peraturan perundang-undangan yang termaktub dalam UUPPLH, ada beberapa proses yang dilalui terlebih dahulu,

Kebanyakan penghasil limbah B3 adalah perusahaan/badan hukum, dan/atau korporasi. Pengertian "setiap" orang dalam Pasal 1 angka (32) UUPPLH, adalah seorang perorangan atau badan usaha baik berbadan hukum maupun yang tidak berbadan hukum. Persekutuan (maatschap, partnership) merupakan dua orang atau lebih mengingkatkan dirinya untuk memberikan berupa uang, barang atau tenaga dalam bentuk suatu kerjasama, yang tujuan kerjasama dimaksud biasanya untuk membagi keuntungan dari hasil kerjasama secara prorata sesuai dengan porsi atau besarnya modal yang dimasukkan Suatu badan hukum merupakan suatu badan (entity) yang keberadaannya terjadi karena hukum atau Undang-Undang dan sebagai subyek hukum secara materil.

\section{Kesimpulan}

Pengimpor Limbah B3 seharusnya dikenai Sanksi Kepidanaan dalam bidang Lingkungan Hidup, mengingat mengimpor Limbah B3 itu dilarang, dan asuk kategori tindakan pidana. Sedang sesuai Undang-Undang Nomor 32 Tahun 2009 Tentang Perlindungan dan Pengelolaan Lingkungan Hidup, sanksi pidana merupakan kejahatan. Penerapan asas Ultimum Remedium bagi pengimpor limbah B3 tidak sepatututnya diterapkan, tapi langsung pada asas Premium

\section{Remedium.}

Pemerintah dan Pemerintah Daerah lebih selektif dalam menerbitkan ijin lingkungang terutama pada perusahaan yang berpotensi memproduksi limbah B3 khususnya industriindustri kapal, karena dalam membuat kapal itu dikenal istilah sandblasting. Sandblasting ini adalah pembersihan karat di plat-plat baja yang disemprotkan dan menghasil partikel-partikel halus berupa debu. Debu tersebut adalah limbah B3 yang sangat berbahaya dan beracun.

Untuk menghindari tindak kejahatan lingkungan diperlukan pengawasan baik sebelum dan setelah beraktivitasnya sebuah perusahaan. Pengawasan ini merupakan bentuk preventif 
sehingga tidak terjadi kerugian para pihak. Tindakan refresif akan merugikan karena konsekuensinya adalah pemutusan hubungan kerja, dan peerintah kehilangan pendapatan dari pajak dan retribusi lainnya.

Namun sanksi yang tepat bagi pengimpor limbah B3 adalah sanksi pidana, dan diterapkan tanggungjawab korporasi, tidak hanya terbatas kepada pengurus dan/atau penanggungjawab perusahaan. Sebab penanggungjawab dan/atau pengurus tidak tertutup kemungkinan orang yang dibawah perintah.

Pemeritah sebagai penyelenggara Negara bertanggungjawab terhadap kelestarian lingkungan. Ini tertuang dalam Undang-Undang Nomor 32 Tahun 2009 Tentang Pengelolaan dan Perlindungan Lingkungan Hidup. Batam sebagai daerah industri tentu saja menyumbang limbah B3 terutama yang dihasilkan oleh industri galangan kapal (shipyard), tanpa mengesampingkan industri lain yang juga penghasil limbah B3.

Meskipun Pemerintah Kota Batam telah membangun Pos Pengaduan soal adanya kerusakan/pencemaran lingkungan hidup sesuai Keputusan Walikota No.Kpts.173/HK/X/2007, namun harus benar-benar diberdayakan sehingga keluhan masyarakat menyangkut limbah B3 segera diketahui, dan dapat dibuat kebijakan agar penyebaran Limbah B3 itu tidak meluas.

Apabila penerapan hukum lingkungan hidup khususnya menyangkut limbah B3 tidak serius, maka Batam akan musibah karena limbah beracun. Perusahaan penghasil Limbah B3 dari tahun ke tahun meningkat. Tahun 2012 sebanyak 397 perusahaan dari prediksi 500 perusahaan industri/penghasil limbah B3 pada tahun 2016. ${ }^{14}$

Surat Badan Pengendalian Dampak Lingkungan Kota Batam Nomor 65/Bapedal/PLH/I/2014 tanggal 26 Januari 2015 menyebutkan, bahwa data jumlah limbah B3 yang dihasilkan di Kota Batam pada 2014 sebanyak 58,856 ton, meningkat pada tahun 2016 sebanyak 94.000 ton, sedang tenaga pengawas sebanyak 18 orang pada tahun 2013, dan berkurang menjadi 15 orang pada $2014 .{ }^{15}$

\section{DAFTAR PUSTAKA.}

\footnotetext{
${ }^{14}$ Data dari Badan Pengendalian Dampak Lingkungan Kota Batam, Surat Nomor 65/Bapedalda/I/2014

15 ibid
} 


\section{A. BUKU}

D.Y.Witanto, Hukum Acara Mediasi Dalam Perkara Perdata di Lingkungan Peradilan Umum dan Peradilan Agama Menurut PERMA No.1 Tahun 2008 Tentang Prosedur Mediasi di Pengadilan, Bandung: Alfabeta, 2011.

Eddy O.S Hiariej, Prinsip-prinsip Hukum Pidana, Yogyakarta: Cahaya Atma Pustaka, 2014

Ridwan HR (Ed.Rev.7), Hukum Administrasi Negara, Jakarta: PT.Grafindo Persada, 2011

Takdir Rahmadi (Cet.ke-2), Hukum Lingkungan di Indonesia, Jakarta: Rajagrafindo, Persada, 2014

\section{B. MAJALAH/KORAN/WORKSHOP DAN SEMINAR}

Majalah Batam Indonesia Free Trade Zone Authority, Development Progress of Batam, Tahun 2014, Edisi 1 Volume XXV, Pusat Pengelolaan Data \& Sistem Informal (PPDSI) Badan Pengusahaan Kawasan Perdagangan Bebas dan Pelabuhan Bebas Batam,

Rapat Stake Holders Eksekutif Pengelolaan Sampah Kota Batam, 21 Nopember 2012 di Hotel Swiss Inn Batam

\section{B. Peraturan perundang-undangan}

Keputusan Presiden Nomor 74 Tahun 1971 Tentang Pengembangan Pulau Batam wilayah Batu Ampar ditetapan sebagai Daerah Industri.-lihat juga Keputusan Presiden Nomor 41 Tahun 1978 Tentang Penetapan Seluruh Daerah Industri Pulau Batam sebagai wilayah usaha Bonded Warehouse

\section{Internet}

Fokky Fuad, Kategori Teori Hukum, Diambil pada 29 Maret 2015 dari https://krisnaptik.wordpress.com

Nining Eka Wahyu Hidayati, Kajian Teori Perlindungan Hukum. Diambil pada 15 Agustus 20015 dari http://hnikawawz.blogspot.com

Irma Anshari, Pengelolaan Limbah dan Penanganan Limbah B3, Diambil pada 29 Agustus 2014 http://limbahb3-limbahb3.blogspot.com 